\title{
Pseudoxanthomonas yeongjuensis sp. nov., isolated from soil cultivated with Korean ginseng
}

Correspondence Soon-Wo Kwon swkwon@rda.go.kr

\author{
Seung-Hee Yoo, ${ }^{1}$ Hang-Yeon Weon, ${ }^{2}$ Byung-Yong Kim, ${ }^{1}$ Jin-Ho Kim, ${ }^{3}$ \\ Youn-Kyung Baek, ${ }^{1}$ Soon-Wo Kwon, ${ }^{1}$ Seung-Joo Go ${ }^{1}$ \\ and Erko Stackebrandt ${ }^{4}$
}
${ }^{1}$ Korean Agricultural Culture Collection (KACC), Microbial Genetics Division, National Institute of Agricultural Biotechnology, Rural Development Administration, Suwon 441-707, Korea
${ }^{2}$ Applied Microbiology Division, National Institute of Agricultural Science and Technology, Rural Development Administration, Suwon 441-707, Korea
${ }^{3}$ Division of Environment and Ecology, National Institute of Agricultural Science and Technology, Rural Development Administration, Suwon 441-707, Korea
${ }^{4}$ Deutsche Sammlung von Mikroorganismen und Zellkulturen $\mathrm{GmbH}$, Inhoffenstrasse 7b, D-38124 Braunschweig, Germany

\begin{abstract}
A Gram-negative, strictly aerobic, non-spore-forming bacterium, motile by means of single polar flagellum and rod-shaped, designated strain GR12-1 ${ }^{\top}$, was isolated from soil of a ginseng field in Yeongju region, Korea. Phylogenetic analysis based on 16S rRNA gene sequences indicated that this strain is related to members of the genus Pseudoxanthomonas, showing sequence similarity values ranged from 92.3 to $96.2 \%$. This organism grew at $5-33^{\circ} \mathrm{C}$, with optimum growth at $28^{\circ} \mathrm{C}$. Strain GR12-1 ${ }^{\top}$ grew optimally in the presence of $0-2 \% \mathrm{NaCl}$. The whole-cell fatty acid profile included iso- $\mathrm{C}_{15: 0}$, iso- $\mathrm{C}_{17: 1} \omega 9 \mathrm{c}$, iso- $\mathrm{C}_{16: 0}$, iso- $\mathrm{C}_{11: 0} 3-\mathrm{OH}$ and iso- $\mathrm{C}_{17: 0}$ as major components. The only isoprenoid quinone was ubiquinone $8(\mathrm{Q}-8)$. The DNA $\mathrm{G}+\mathrm{C}$ content was $63.4 \mathrm{~mol} \%$. On the basis of phenotypic, genetic and phylogenetic data, strain GR12-1 ${ }^{\top}$ should be classified as a member of a novel species of the genus Pseudoxanthomonas, for which the name Pseudoxanthomonas yeongjuensis sp. nov. is proposed, with strain GR12-1 ${ }^{\top}$ $\left(=\right.$ KACC $11580^{\top}=$ DSM $\left.18204^{\top}\right)$ as the type strain.
\end{abstract}

The genus Pseudoxanthomonas was first proposed by Finkmann et al. (2000) and was classified into the family Xanthomonadaceae, order Xanthomonadales, class Gammaproteobacteria and phylum Proteobacteria (Garrity \& Holt, 2001). The genus Pseudoxanthomonas comprises nine species, which were isolated from biofilters (Finkmann et al., 2000), sludge (Thierry et al., 2004), a hot spring (Chen et al., 2002), soils (Thierry et al., 2004; Chang et al., 2005; Yang et al., 2005; Harada et al., 2006) and compost (Weon et al., 2006). The type species is Pseudoxanthomonas broegbernensis.

Strain GR12-1 ${ }^{\mathrm{T}}$ was isolated from a field cultivated with Korean ginseng (Panax ginseng C. A. Meyer) in Yeongju region, Korea. For the isolation, a soil sample was diluted serially in saline solution $(0.85 \% \mathrm{w} / \mathrm{v})$. The diluted soil sample was spread on R2A and incubated for 3 days at $28^{\circ} \mathrm{C}$.

The GenBank/EMBL/DDBJ accession number for the $16 \mathrm{~S}$ rRNA gene sequence of strain GR12-1 ${ }^{\top}$ is DQ.438977.

Details of the fatty acid composition of strain GR $12-1^{\top}$ and related strains are available as supplementary material in IJSEM Online.
The isolate was routinely cultivated on R2A for 2 days at $28{ }^{\circ} \mathrm{C}$ except where indicated otherwise.

Cellular morphology was determined by transmission electron microscopy (TEM) and phase-contrast microscopy using 1- or 2-day-old cells. The temperature range, $\mathrm{pH}$ range and $\mathrm{NaCl}(\mathrm{w} / \mathrm{v})$ requirement were determined according to Weon et al. (2006). Anaerobic growth was checked using BBL anaerobic jars (Becton Dickinson). Gram staining and tests for catalase, oxidase, indole production and hydrolysis of casein, DNA, gelatin and starch were conducted according to the methods of Smibert \& Krieg (1994). Carboxymethylcellulose (Sigma) for the cellulase test and tyrosine $(0.5 \%, \mathrm{w} / \mathrm{v})$ were also used. For nitrate and nitrite reduction tests, strain GR12-1 ${ }^{\mathrm{T}}$ was inoculated into three serum bottles $(25 \mathrm{ml}$ ) each containing $13 \mathrm{ml} \mathrm{R} 2 \mathrm{~A}$ media, while nitrate and nitrite were added as $\mathrm{KNO}_{3}$ and $\mathrm{NaNO}_{2}$ at concentrations of $10 \mathrm{mM}$. The reduction of nitrate and nitrite was monitored by ion chromatography (model IC320; Dionex). In addition, tests in the commercial systems API 20NE and API ZYM (bioMérieux) were performed according to the manufacturer's instructions. The API ZYM 
tests were read after $4 \mathrm{~h}$ incubation at $37^{\circ} \mathrm{C}$ and the other API tests after $48 \mathrm{~h}$ at $28^{\circ} \mathrm{C}$.

The strain grew well on R2A and nutrient agar (NA; Difco), but did not grow MacConkey agar (Difco). After subcultures on trypticase soy agar (TSA; Difco), it showed poor growth. The colonies were circular, 1-2 $\mathrm{mm}$ in diameter, convex and greenish yellow on R2A. After prolonged incubation ( $>2$ weeks), the centres of the colonies displayed a brown spot. Detailed morphological and physiological properties are shown in Table 1 and are given in the species description.

Genomic DNA was isolated by the method of Ausubel et al. (1987), except that lysates were extracted twice with chloroform to remove residual phenol. The $\mathrm{G}+\mathrm{C}$ content of genomic DNA was determined by HPLC as described previously (Mesbah et al., 1989). The G+C content of the DNA of strain GR12- $1^{\mathrm{T}}$ was $63.4 \mathrm{~mol} \%$, a value within the range (60.1-70.1 mol\%) reported for the genus Pseudoxanthomonas (Harada et al., 2006). Isoprenoid quinones were analysed by HPLC as described previously (Groth et al., 1996). Ubiquinone 8 (Q-8) was the only isoprenoid quinone.

For analysis of fatty acids, the strain was grown at $28^{\circ} \mathrm{C}$ on TSA. Cells were harvested after $48 \mathrm{~h}$ and identification of fatty acids was performed by the standard protocol of the Microbial Identification System (MIDI; Microbial ID)
(Sasser, 1990). The major cellular fatty acids of strain GR12-1 ${ }^{\mathrm{T}}$ were iso- $\mathrm{C}_{15: 0}(32.0 \%)$, iso- $\mathrm{C}_{17: 1} \omega 9 c(14.6 \%)$, iso- $\mathrm{C}_{16: 0}(13.3 \%)$, iso- $\mathrm{C}_{11: 0} 3-\mathrm{OH}(7.7 \%)$ and iso- $\mathrm{C}_{17: 0}$ $(6.4 \%)$. Considering the five major cellular fatty acids, the cellular fatty acid profile of the new isolate is similar to that of Pseudoxanthomonas japonensis $12-3^{\mathrm{T}}$ (see Supplementary Table S1 available in IJSEM Online).

The 16S rRNA gene sequence was determined by PCR amplification (Kwon et al., 2003) and direct sequencing (Hiraishi, 1992). The nearly complete sequence of the 16S rRNA gene (1455 nt) was determined. Phylogenetic analysis was performed using MEGA version 2.1 (Kumar et al., 2001). Nucleotide substitution rates were calculated using the twoparameter method of Kimura (1980). The phylogenetic tree was inferred using the neighbour-joining method (Saitou \& Nei, 1987) and bootstrap analysis based on 1000 replications was undertaken to test the robustness of the phylogenetic tree (Felsenstein, 1985). According to the phylogenetic tree (Fig. 1), strain GR $12-1^{\mathrm{T}}$ was loosely related to the members of the genus Pseudoxanthomonas with relative low bootstrap values $(37 \%)$. The sequence similarities of GR $12-1^{\mathrm{T}}$ to the type strains of the genus Pseudoxanthomonas ranged from 92.3 to $96.2 \%$, and the sequence similarity of strain GR12$1^{\mathrm{T}}$ to species of other genera within the family Xanthomonadaceae was below $95 \%$.

Table 1. Differential characteristics of strain GR12-1 ${ }^{\top}$ and other Pseudoxanthomonas species

Taxa: 1, GR12-1 ${ }^{\mathrm{T}}$; 2, P. broegbernensis; 3, P. daejeonensis; 4, P. japonensis; 5, P. kalamensis; 6, P. kaohsiungensis; 7, P. koreensis; 8, P. mexicana; 9, P. suwonensis; 10, P. taiwanensis. Data are from Finkmann et al. (2000), Chen et al. (2002), Thierry et al. (2004), Chang et al. (2005), Yang et al. (2005), Weon et al. (2006), Harada et al. (2006) and this study. +, Positive; -, negative; w, weak reaction; ND, not determined/no data available.

\begin{tabular}{|c|c|c|c|c|c|c|c|c|c|c|}
\hline Characteristic & 1 & 2 & 3 & 4 & 5 & 6 & 7 & 8 & 9 & 10 \\
\hline Motility & + & + & + & + & - & + & - & + & + & - \\
\hline Optimum temperature $\left({ }^{\circ} \mathrm{C}\right)$ & 28 & 30 & 30 & $30-37$ & $30-37$ & 35 & 30 & $30-37$ & 30 & 50 \\
\hline Growth at $10^{\circ} \mathrm{C}$ & + & + & $\mathrm{W}$ & + & + & + & $\mathrm{W}$ & + & + & - \\
\hline Growth at $42^{\circ} \mathrm{C}$ & - & - & - & - & - & - & - & - & + & + \\
\hline Aesculin & + & + & + & + & + & + & - & + & + & + \\
\hline Casein & + & - & + & + & $\mathrm{ND}$ & $\mathrm{ND}$ & + & + & - & - \\
\hline Gelatin & + & - & - & + & - & - & - & + & + & - \\
\hline Urea & - & - & - & - & - & - & + & - & - & ND \\
\hline \multicolumn{11}{|l|}{ Assimilation of: } \\
\hline$N$-Acetylglucosamine & + & + & + & + & + & + & - & $\mathrm{ND}$ & + & ND \\
\hline D-Maltose & + & + & + & + & + & + & - & + & + & - \\
\hline Citrate & - & + & - & - & - & - & - & - & - & ND \\
\hline DNA G + C content $(\mathrm{mol} \%)$ & 63.4 & $66.5 \pm 0.8$ & $68.7 \pm 0.4$ & $65.2 \pm 1$ & 64.0 & 60.1 & $69.5 \pm 0.5$ & $67.8 \pm 2$ & $66.6-68.4$ & $70.0 \pm 0.1$ \\
\hline
\end{tabular}






Fig. 1. Phylogenetic tree constructed using the neighbour-joining method based on $16 \mathrm{~S}$ rRNA gene sequences showing the position of strain GR12-1 ${ }^{\top}$. Bootstrap percentage values (1000 tree replications) greater than $50 \%$ are indicated at branch points. Bar, 5 substitutions per $1000 \mathrm{nt}$.
The genera Pseudoxanthomonas, Xanthomonas and Stenotrophomonas within the family Xanthomonadaceae are very similar in their phenotypic and chemotaxonomic traits. However, the ability to reduce nitrite and not nitrate to $\mathrm{N}_{2} \mathrm{O}$ and the absence of the fatty acid iso- $\mathrm{C}_{13: 0} 3-\mathrm{OH}$ are important traits of the genus Pseudoxanthomonas that allow it to be separated from the genera Xanthomonas and Stenotrophomonas (Thierry et al., 2004; Harada et al., 2006). Strain GR $12-1^{\mathrm{T}}$ can be classified in the genus Pseudoxanthomonas in that it shows the absence of the fatty acid iso- $\mathrm{C}_{13: 0} 3-\mathrm{OH}$ and nitrate reduction to $\mathrm{N}_{2} \mathrm{O}$ and the presence of nitrite reduction ability, as well as relatively high sequence similarities (92.3-96.2\%) to members of the genus Pseudoxanthomonas. From phenotypic comparison among Pseudoxanthomonas species (Table 1), strain GR12-1 ${ }^{\mathrm{T}}$ could be differentiated on the basis of several phenotypic traits. For example, strain GR $12-1^{\mathrm{T}}$ can be differentiated from $P$. koreensis and $P$. taiwanensis in the presence of motility and the absence of gelatin hydrolysis and L-arabinose assimilation. We therefore propose that strain GR12-1 ${ }^{\mathrm{T}}$ should be classified within a novel species within the genus Pseudoxanthomonas, Pseudoxanthomonas yeongjuensis sp. nov.

\section{Description of Pseudoxanthomonas yeongjuensis sp. nov.}

Pseudoxanthomonas yeongjuensis (ye.ong.ju.en'sis. N.L. fem. adj. yeongjuensis pertaining to Yeongju province in Korea, from where the type strain was isolated).

Cells are Gram-negative, oxidase- and catalase-positive, non-spore-forming, rod-shaped $(0.7-0.8 \times 1.8-2.5 \mu \mathrm{m})$ and motile by means of single polar flagellum. After 2 days incubation on $\mathrm{R} 2 \mathrm{~A}$ at $28^{\circ} \mathrm{C}$, colonies are circular, 1-2 $\mathrm{mm}$ in diameter, convex and greenish yellow. Older colonies (incubation of 2 weeks) form a brown spot in the centre. Grows well at $5-33^{\circ} \mathrm{C}$ (optimum at $28^{\circ} \mathrm{C}$ ), in the presence of $0-2 \% \mathrm{NaCl}(\mathrm{w} / \mathrm{v})$ and at $\mathrm{pH} 6-8$. It reduces nitrite, but does not reduce nitrate. Positive for aesculin hydrolysis, gelatin hydrolysis, $\beta$-galactosidase, alkaline phosphatase, esterase (C4), esterase lipase (C8), $\alpha$-chymotrypsin, acid phosphatase and naphthol-AS-BI-phosphohydrolase and negative for nitrate reduction, indole production, glucose fermentation, arginine dihydrolase, urease, lipase (C14), leucine arylamidase, valine arylamidase, cystine arylamidase, trypsin, $\alpha$-galactosidase, $\beta$-glucuronidase, $\alpha$-glucosidase, $\beta$-glucosidase, $N$-acetyl- $\beta$ glucosaminidase, $\alpha$-mannosidase, $\alpha$-fucosidase. Assimilates D-glucose, $N$-acetylglucosamine and D-maltose, but does not assimilate L-arabinose, D-mannose, D-mannitol, potassium gluconate, capric acid, adipic acid, malic acid, trisodium citrate or phenylacetic acid. The major cellular fatty acids are iso- $\mathrm{C}_{15: 0}$, iso- $\mathrm{C}_{17: 1} \omega 9 c$, iso- $\mathrm{C}_{16: 0}$, iso- $\mathrm{C}_{11: 0}$ $3-\mathrm{OH}$ and iso- $\mathrm{C}_{17: 0}$. Ubiquinone $8(\mathrm{Q}-8)$ is the only isoprenoid quinone. The $\mathrm{G}+\mathrm{C}$ content is $63.4 \mathrm{~mol} \%$.

The type strain, GR $12-1^{\mathrm{T}}\left(=\operatorname{KACC} 11580^{\mathrm{T}}=\mathrm{DSM} 18204^{\mathrm{T}}\right)$, was isolated from soil of a ginseng field in Korea.

\section{Acknowledgements}

This study was supported by a programme of international co-research work between the Rural Development Administration (RDA), Korea, and the DSMZ, Germany.

\section{References}

Ausubel, F. M., Brent, R., Kingston, R. E., Moore, D. D., Seidman, J. G., Smith, J. A. \& Struhl, K. (editors) (1987). Current Protocols in Molecular Biology. New York: Greene/Wiley Interscience.

Chang, J. S., Chou, C. L., Lin, G. H., Sheu, S. Y. \& Chen, W. M. (2005). Pseudoxanthomonas kaohsiungensis, sp. nov., a novel bacterium isolated from oil-polluted site produces extracellular surface activity. Syst Appl Microbiol 28, 137-144.

Chen, M. Y., Tsay, S. S., Chen, K. Y., Shi, Y. C., Lin, Y. T. \& Lin, G. H. (2002). Pseudoxanthomonas taiwanensis sp. nov., a novel thermophilic, $\mathrm{N}_{2} \mathrm{O}$-producing species isolated from hot springs. Int J Syst Evol Microbiol 52, 2155-2161.

Felsenstein, J. (1985). Confidence limits on phylogenies: an approach using the bootstrap. Evolution 39, 783-791.

Finkmann, W., Altendorf, K., Stackebrandt, E. \& Lipski, A. (2000). Characterization of $\mathrm{N}_{2} \mathrm{O}$-producing Xanthomonas-like isolates from biofilters as Stenotrophomonas nitritireducens sp. nov., Luteimonas mephitis gen. nov., sp. nov. and Pseudoxanthomonas broegbernensis gen. nov., sp. nov. Int J Syst Evol Microbiol 50, 273-282. 
Garrity, G. M. \& Holt, J. G. (2001). The roadmap to the Manual. In Bergey's Manual of Systematic Bacteriology, 2nd edn, vol. 1, pp. 119-166. Edited by G. M. Garrity, D. R. Boone \& R. W. Castenholz. New York: Springer.

Groth, I., Schumann, P., Weiss, N., Martin, K. \& Rainey, F. A. (1996). Agrococcus jenensis gen. nov., sp. nov., a new genus of actinomycetes with diaminobutyric acid in the cell wall. Int J Syst Bacteriol 46, 234-239.

Harada, R. M., Campbell, S. \& Li, Q. X. (2006). Pseudoxanthomonas kalamensis sp. nov., a novel gammaproteobacterium isolated from Johnston Atoll, North Pacific Ocean. Int J Syst Evol Microbiol 56, 1103-1107.

Hiraishi, A. (1992). Direct automated sequencing of $16 \mathrm{~S}$ rDNA amplified by polymerase chain reaction from bacterial cultures without DNA purification. Lett Appl Microbiol 15, 210-213.

Kimura, M. (1980). A simple method for estimating evolutionary rates of base substitutions through comparative studies of nucleotide sequences. J Mol Evol 16, 111-120.

Kumar, S., Tamura, K., Jakobsen, I. B. \& Nei, M. (2001). MEGA2: molecular evolutionary genetics analysis software. Bioinformatics 17, 1244-1245.

Kwon, S. W., Kim, J. S., Park, I. C., Yoon, S. H., Park, D. H., Lim, C. K. \& Go, S. J. (2003). Pseudomonas koreensis sp. nov., Pseudomonas umsongensis sp. nov. and Pseudomonas jinjuensis sp. nov., novel species from farm soils in Korea. Int J Syst Evol Microbiol 53, 21-27.
Mesbah, M., Premachandran, U. \& Whitman, W. B. (1989). Precise measurement of the $\mathrm{G}+\mathrm{C}$ content of deoxyribonucleic acid by highperformance liquid chromatography. Int J Syst Bacteriol 39, 159-167.

Saitou, N. \& Nei, M. (1987). The neighbor-joining method: a new method for reconstructing phylogenetic trees. Mol Biol Evol 4, 406-425.

Sasser, M. (1990). Identification of bacteria by gas chromatography of cellular fatty acids. Technical Note no. 101. Newark, DE: MIDI Inc.

Smibert, R. M. \& Krieg, N. R. (1994). Phenotypic characterization. In Methods for General and Molecular Bacteriology, pp. 607-654. Edited by P. Gerhardt, R. G. E. Murray, W. A. Wood \& N. R. Krieg. Washington, DC: American Society for Microbiology.

Thierry, S., Macarie, H., lizuka, T., Geißdörfer, W., Assih, E. A., Spanevello, M., Verhe, F., Thomas, P., Fudou, R. \& other authors (2004). Pseudoxanthomonas mexicana sp. nov. and Pseudoxanthomonas japonensis sp. nov., isolated from diverse environments, and emended descriptions of the genus Pseudoxanthomonas Finkmann et al. 2000 and of its type species. Int J Syst Evol Microbiol 54, 2245-2255.

Weon, H. Y., Kim, B. Y., Kim, J. S., Lee, S. Y., Cho, Y. H., Go, S. J., Hong, S. B., Im, W. T. \& Kwon, S. W. (2006). Pseudoxanthomonas suwonensis sp. nov., isolated from cotton waste composts. Int J Syst Evol Microbiol 56, 659-662.

Yang, D.-C., Im, W.-T., Kim, M. K. \& Lee, S.-T. (2005). Pseudoxanthomonas koreensis sp. nov. and Pseudoxanthomonas daejeonensis sp. nov. Int J Syst Evol Microbiol 55, 787-791. 